\title{
Intercropping of soybean cultivars with Urochloa ${ }^{1}$
}

\author{
Julio Cezar Franchini², Alvadi Antonio Balbinot Junior ${ }^{2}$, \\ Henrique Debiasi ${ }^{2}$, Sergio de Oliveira Procópio ${ }^{3}$
}

\section{RESUMO}

Cultivo integrado de cultivares de soja e braquiária

A integração lavoura-pecuária (ILP) tem demonstrado benefícios tanto para a produção de grãos, quanto para a pecuária. O cultivo de espécies forrageiras entre duas safras de soja é uma forma importante de ILP, no Brasil. Este trabalho objetivou avaliar a produtividade de cultivares de soja resistentes ao glifosato, cultivadas em integração com espécies gramíneas do gênero Urochloa, em diferentes formas de manejo do capim. Foram conduzidos seis experimentos, constituídos pela combinação de três cultivares de soja (BRS 295 RR, BRS 316 RR e BRS 294 RR) e duas espécies de gramíneas forrageiras (Urochloa ruziziensis e Urochloa brizantha). Foram avaliados quatro tratamentos (soja em cultivo solteiro; forrageira em cultivo solteiro; cultivo integrado de soja e uma espécie forrageira, com aplicação de glifosato, para reduzir o crescimento das gramíneas; e cultivo integrado de soja e uma espécie forrageira, sem supressão do crescimento), em delineamento experimental inteiramente casualizado, com quatro repetições. Em cada experimento, foi utilizada somente uma cultivar de soja e uma espécie forrageira. As gramíneas foram semeadas nas entrelinhas da soja, aos 27 dias após a semeadura (DAS), enquanto a aplicação de glifosato, no tratamento com supressão das forrageiras, foi realizada aos 84 DAS da soja ou 57 DAS das forrageiras. A produtividade das três cultivares não foi significativamente afetada pela interferência das gramíneas, e a produção de massa seca da parte aérea, para as gramíneas cultivadas em integração, foi alta, embora com valores inferiores aos obtidos sem a interferência imposta pela soja.

PALAVRAS-CHAVE: Glycine max; Urochloa ruziziensis; Urochloa brizantha; plantio direto; integração lavoura-pecuária.

\section{INTRODUCTION}

The optimization of agricultural land uses, with a view to maximizing the use of water, light, nutrients, machines, and hand labor, is essential for the sustainability of agribusiness. One way to achieve such objectives is the implementation of an integrated

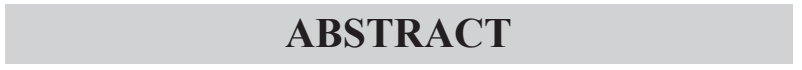

The integrated crop-livestock system is a key strategy for both grain and livestock production. The cultivation of grass species in between two soybean cropping seasons has been an important component of this system, in Brazil. Thus, this study aimed to evaluate the yield of glyphosate-resistant soybean cultivars intercropped with Urochloa species, under different forage management systems. A total of six experiments, consisting of three soybean cultivars (BRS 295 RR, BRS 316 RR, and BRS 294 RR) and two grass species (Urochloa ruziziensis and Urochloa brizantha), were established. For each experiment, four treatments (soybean only; grass only; soybean intercropped with a grass species, with the application of glyphosate to decrease the growth of grass; and soybean intercropped with a grass species, without growth suppression) were evaluated in a completely randomized experimental design, with four replications. For each experiment, only one soybean cultivar and one grass species were used. The grasses were sown in the soybean inter-rows at 27 days after sowing (DAS), while the glyphosate application to the treatment with grass suppression was performed at 84 DAS for the soybean or 57 DAS for the grasses. The yields of the three soybean cultivars were not significantly affected by either grass species, even though the shoot dry-matter yields for both of the intercropped grass species were high, though lower than the values obtained without the interference imposed by soybean.

KEY-WORDS: Glycine max; Urochloa ruziziensis; Urochloa brizantha; no-tillage system; integrated crop-livestock system.

crop-livestock farming system (CLS) (Balbino et al. 2011). In Brazil, there are diverse forms of CLS, and the cultivation of annual pastures in between two summer crop periods is increasingly practiced (Balbinot Junior et al. 2009, Veiga et al. 2012). In this CLS modality, the cultivation of grass species is common. The grass is used as pasture during the

1. Article received in Jun./2013 and accepted for publication in Mar./2014 (Registration number: PAT 24551)

2. Empresa Brasileira de Pesquisa Agropecuária (Embrapa), Embrapa Soja, Londrina, PR, Brasil.

E-mails: julio.franchini@embrapa.br, alvadi.balbinot@embrapa.br, henrique.debiasi@embrapa.br.

3. Empresa Brasileira de Pesquisa Agropecuária (Embrapa), Embrapa Tabuleiros Costeiros, Aracajú, SE, Brasil. E-mail: sergio.procopio@embrapa.br. 
fallow period between two soybean cropping seasons (i.e., from March to September).

The association of CLS with no-tillage system (NTS) allows for increased economic returns and contributes to preserve the environment. The use of NTS increases the stability of crop production, with minimal environmental disturbance (Franchini et al. 2012). However, the long-term sustainability of NTS requires the implementation of crop rotations, minimum soil disturbance, and the cultivation of species with high longevity of straw, such as those of the Urochloa genus (Silva et al. 2004).

In tropical and subtropical regions, various Urochloa species may be used for fodder production between two summer cropping seasons. Nevertheless, when these species are sown at the end of the rainy period, the productivity of the pasture has been low, thus compromising the supply of fodder during dry months (June to August). Therefore, the establishment of fodder grasses before soybean harvest is an alternative that can ensure adequate production of fodder during the period of low water availability. A strategy that can be successfully implemented without causing a significant reduction in the soybean yield is the intercropping between soybean and grass using a high-yield species, such as Urochloa (Silva et al. 2004).

Intercropping with various plant species is an ancient cultural practice, largely used in agriculture to increase crop yield by enhancing the exploitation of resources available to the farmer (Silva et al. 2006). Studies have shown that intercropping between soybean and Urochloa brizantha can reduce soybean yields as a consequence of the competition for resources (Silva et al. 2004). Thus, further studies are required to investigate the viability of intercropping various soybean cultivars and grass species without reducing grain yield.

The morpho-physiological characteristics of soybean plants define their competitive ability with fodder plants (Silva et al. 2004). A study conducted by Fleck et al. (2007) indicates that the growth rate of a soybean plant is the key factor that reduces the interference generated by other plants. Moreover, the authors explain that the plant height and the ability to branch can determine the competitiveness of the soybean. Therefore, it is important to identify soybean cultivars more adapted to the level of competition produced by intercropping with fodder plants.
This study aimed to assess the productivity and performance of three glyphosate-resistant soybean cultivars and two species of Urochloa, when intercropped, as well as the efficiency of the land use for different soybean-grass intercropped systems.

\section{MATERIAL AND METHODS}

The experiments were carried out in Londrina, Paraná State, southern Brazil $\left(23^{\circ} 11^{\prime} \mathrm{S}, 51^{\circ} 11^{\prime} \mathrm{W}\right.$, altitude $620 \mathrm{~m}$ ), during the 2011/2012 cropping season. The climate of the region is classified as humid subtropical (Cfa, according to Köppen's classification). The mean monthly air temperature and precipitation during the experimental period are presented in Figure 1.

The soil of the experimental site is classified as a Red Eutroferric Latosol by the Brazilian Soils Classification System (SiBCS) (Embrapa 2006), equivalent to an Oxisol by the United States Department of Agriculture (USDA) soil classification system. Some soil physical and chemical properties of the topsoil $(0-20 \mathrm{~cm})$ are as it follows: clay $=710 \mathrm{~g} \mathrm{~kg}^{-1}$; silt $=82 \mathrm{~g} \mathrm{~kg}^{-1}$; sand $=208 \mathrm{~g} \mathrm{~kg}^{-1}$; organic carbon $=$ $8.3 \mathrm{~g} \mathrm{dm}^{-3} ; \mathrm{pH}\left(\mathrm{CaCl}_{2}\right)=5.1 ; \mathrm{P}=18.6 \mathrm{mg} \mathrm{dm}^{-3}$; $\mathrm{K}=0.37 \mathrm{cmolc} \mathrm{dm}^{-3} ; \mathrm{Ca}=3.4 \mathrm{cmolc} \mathrm{dm}^{-3} ;$ and $\mathrm{Mg}=1.4 \mathrm{cmolc} \mathrm{dm}^{-3}$. The soil in the experimental site has been managed under NTS since 2006, and prior to the experiment, the area was cultivated with soybean and maize (Zea mays L.) in the summer and wheat (Triticum aestivum L.) in the winter.

Six experiments were carried out simultaneously under NTS, in a completely randomized

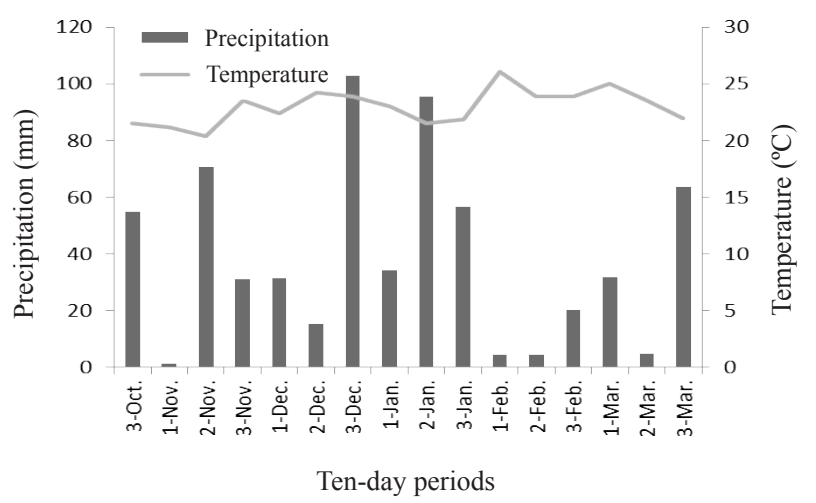

Figure 1. Mean precipitation and air temperature during the 2011/2012 cropping season (Londrina, Paraná State, southern Brazil). 
design, with four replications. For each experiment, four treatments were evaluated: T1) soybean only; T2) fodder grass only; T3) soybean intercropped with fodder grass + glyphosate application $\left(180 \mathrm{~g}\right.$ a.i. ha $\left.^{-1}\right)$ to suppress the growth of grass; and T4) soybean intercropped with fodder grass, without glyphosate application.

For each experiment, one of the three soybean cultivars (BRS 295 RR, BRS 316 RR and BRS 294 $\mathrm{RR})$ and one species of Urochloa [U. ruziziensis (Germain \& Evrard) Morr. \& Zuloaga or U. brizantha (Hochst. ex. A. Rich) Stapf.] were included, i.e., Experiment 1: BRS 295 RR x U. ruziziensis; Experiment 2: BRS $316 \mathrm{RR}$ x U. ruziziensis; Experiment 3: BRS 294 RR x U. ruziziensis; Experiment 4: BRS 295 RR x U. brizantha; Experiment 5: BRS $316 \mathrm{RR} \times$ U. brizantha; and Experiment 6: BRS 294 x U. brizantha.

Soybean was sown on $11 / 11 / 2011$ by using a seeder with independent seed and fertilizer compartments. The sowing was initiated after the chemical desiccation of weeds and a cover crop (Avena strigosa) with glyphosate (720 g a.i. ha $\left.{ }^{-1}\right)$. The soil was fertilized using the recommended application rate of $300 \mathrm{~kg} \mathrm{ha}^{-1}$ of NPK (00-20-20). Prior to sowing, the soybean seeds were treated with carboxin and thiram at the rate of $60 \mathrm{~g}$ a.i. $100 \mathrm{~kg}^{-1}$ of seed and inoculated with Bradyrhizobium elkanii and $B$. japonicum strains using a liquid formulation. In addition, $2 \mathrm{~g} \mathrm{ha}^{-1}$ of cobalt, in the form of cobalt chloride, and $20 \mathrm{~g} \mathrm{ha}^{-1}$ of molybdenum, in the form of sodium molybdate, were applied to the seeds. The spacing between the soybean rows was $0.60 \mathrm{~m}$ to allow for the intercropping of the fodder grasses between rows and to avoid mechanical damage to the soybean seedlings, producing a soybean plant density of approximately 200,000 plants ha- ${ }^{-1}$.

After the soybean emergence (11/30/2012), chemical weed control was performed by applying glyphosate at the rate of $720 \mathrm{~g}$ a.i. ha ${ }^{-1}$. Both fodder grass species were sown between their respective soybean rows at 27 days after sowing (DAS), when the soybean plants were between the V3 and V4 stages. The sowing of the fodder grasses was performed using the same seeder that was used for the soybeans, but with an adapted fluted roller type seed meter that is specific for fodder grass seeds, and the seeds were sown at a depth of $3 \mathrm{~cm}$. Approximately $7 \mathrm{~kg} \mathrm{ha}^{-1}$ of pure and viable $U$. ruziziensis and $U$. brizantha seeds were used for sowing.
For all the experiments, the application of glyphosate to the T3 plots was performed at 84 DAS of soybean and 57 DAS of fodder grasses. For the $\mathrm{T} 1$ treatments, the fodder grasses were desiccated soon after their emergence with the application of glyphosate at a dosage of $1.8 \mathrm{~g}$ a.i. $\mathrm{kg}^{-1}$. In the T2 plots, the soybean plants were cut immediately after the emergence of fodder grass seedlings. For all herbicide applications, a tractor-mounted boom sprayer calibrated to spray the recommended $200 \mathrm{~L} \mathrm{ha}^{-1}$ of herbicide solution was employed. The spray nozzle was an AVI Twin 110.03. The total area of the plots was $28.8 \mathrm{~m}^{2}$, with a net area of $9.6 \mathrm{~m}^{2}$.

At harvest, 10 soybean plants were randomly harvested within the net area of each plot for the determination of number of branches per plant, first pod insertion height, plant height, and yield components (number of pods per plant, number of grains per pod, and 1,000-grain weight). All the soybean plants within the net area of each plot were harvested and threshed on $03 / 26 / 2012$. Then, the grains from each plot were weighted and the crop grain yield was corrected to a moisture content of $13 \%$. The height of the fodder grasses was assessed, based on the mean of 10 measurements per plot. The shoot dry mass production was determined by harvesting a $1 \mathrm{~m}^{2}$ area of each plot. The relative efficiency of intercropping was estimated using the Land Use Efficiency index (LUE) (Andrew \& Kassam 1976), according to the following equation: LUE $=\mathrm{Y}_{\mathrm{AB}} / \mathrm{Y}_{\mathrm{AA}}+\mathrm{Y}_{\mathrm{BA}} / \mathrm{Y}_{\mathrm{BB}}$, where: $\mathrm{Y}_{\mathrm{AB}}=$ yield of species $\mathrm{A}$ intercropped with species $\mathrm{B} ; \mathrm{Y}_{\mathrm{AA}}=$ yield of species $A$ grown alone; $Y_{B A}=$ yield of species $B$ intercropped with species $A$; and $Y_{B B}=$ yield of species B grown alone.

The LUE data are descriptive, thus they were not statistically analyzed. The remaining data were analyzed by Anova ( $F$ test, $\mathrm{p}<0.05$ ) to determine if the differences among treatments were significant. When a treatment effect was detected, the means were compared by performing the Tukey's HSD test $(\mathrm{p}<0.05)$. The shoot dry mass data of the fodder grasses were transformed by $\mathrm{y}=\sqrt{\mathrm{x}}$, due to the lack of homogeneity of variance. The Sisvar software was used to perform the statistical analyses (Ferreira 2008).

\section{RESULTS AND DISCUSSION}

Two periods with very low rainfall were observed during the soybean growth cycle: one 
during the second ten-day period of December, when the plants were at the V3-V4 stage, and another period in February, when the plants were at the R5 stage (Figure 1).

Neither the first pod insertion height nor the height of the soybean plants differed significantly among the various intercropping treatments (Tables 1 and 2). These results indicate the low level of competition for water, light, and nutrients imposed by fodder grasses.

In terms of the number of branches per soybean plant, cv. BRS 295 RR was not influenced by the intercropping of either Urochloa species (Tables 1 and 2). However, cv. BRS 316 RR plants performed better in the absence of $U$. ruziziensis, in comparison to the treatment with the forage species grown under suppression by glyphosate (Table 1). Similarly, cv. BRS 294 RR exhibited higher ramification in the absence of $U$. brizantha, when compared to the treatment in which the growth of this fodder grass was not suppressed (Table 2). Thus, the interference of the fodder grasses was more highly reflected by the ramification of soybean plants than either the first pod insertion height or plant

Table 1. Growth characteristics of the three soybean cultivars, when grown under different cropping treatments with the fodder grass Urochloa ruziziensis, during the 2011/2012 growing season (Londrina, Paraná State, southern Brazil).

\begin{tabular}{|c|c|c|c|}
\hline Treatment & $\begin{array}{l}\text { Number of } \\
\text { branches per } \\
\text { plant }\end{array}$ & $\begin{array}{l}\text { First pod } \\
\text { insertion } \\
\text { height }(\mathrm{cm})\end{array}$ & $\begin{array}{l}\text { Plant } \\
\text { height } \\
(\mathrm{cm})\end{array}$ \\
\hline & \multicolumn{3}{|c|}{ Soybean cv. BRS 295 RR (Experiment 1) } \\
\hline T3 & $2.35 \mathrm{a}^{*}$ & $16.3 \mathrm{a}$ & $91.6 \mathrm{a}$ \\
\hline $\mathrm{T} 4$ & $2.97 \mathrm{a}$ & $16.0 \mathrm{a}$ & $94.1 \mathrm{a}$ \\
\hline $\mathrm{T} 1$ & $2.35 \mathrm{a}$ & $16.3 \mathrm{a}$ & $90.8 \mathrm{a}$ \\
\hline \multirow[t]{2}{*}{$\mathrm{CV}(\%)$} & 23.8 & 10.3 & 5.7 \\
\hline & \multicolumn{3}{|c|}{ Soybean cv. BRS 316 RR (Experiment 2) } \\
\hline $\mathrm{T} 3$ & $2.20 \mathrm{~b}$ & $22.7 \mathrm{a}$ & $91.3 \mathrm{a}$ \\
\hline $\mathrm{T} 4$ & $2.37 \mathrm{ab}$ & $22.5 \mathrm{a}$ & $100.0 \mathrm{a}$ \\
\hline $\mathrm{T} 1$ & $4.52 \mathrm{a}$ & $23.0 \mathrm{a}$ & $100.0 \mathrm{a}$ \\
\hline \multirow[t]{2}{*}{$\mathrm{CV}(\%)$} & 36.5 & 8.8 & 8.6 \\
\hline & \multicolumn{3}{|c|}{ Soybean cv. BRS 294 RR (Experiment 3) } \\
\hline $\mathrm{T} 3$ & $4.17 \mathrm{a}$ & $13.4 \mathrm{a}$ & $74.0 \mathrm{a}$ \\
\hline $\mathrm{T} 4$ & $3.27 \mathrm{a}$ & $13.3 \mathrm{a}$ & $80.3 \mathrm{a}$ \\
\hline $\mathrm{T} 1$ & $4.25 \mathrm{a}$ & $11.7 \mathrm{a}$ & $71.7 \mathrm{a}$ \\
\hline CV (\%) & 33.1 & 17.2 & 8.2 \\
\hline \multicolumn{4}{|c|}{$\begin{array}{l}\text { Means followed by the same letter within a column do not differ significantly } \\
\text { among each other by the Tukey's HSD test ( }>0.05 \text { ), considering each experiment } \\
\text { individually. T3: soybean with fodder grass, with growth suppressed by glyposate; } \\
\text { T4: soybean with fodder grass, without growth suppression; T1: soybean only, } \\
\text { without the fodder grass. }\end{array}$} \\
\hline
\end{tabular}

height. Fleck et al. (2004) found large reductions in soybean ramification associated with the impacts of hair beggar ticks (Bidens pilosa) and arrowleaf sida (Sida rhombifolia).

For all three soybean cultivars, the yield components (number of pods per plant, number of grains per pod, and 1,000-grain weight) did not differ significantly, when intercropped with $U$. ruziziensis and compared to when grown without this fodder grass (Table 3). However, when intercropped with U. ruziziensis, the soybean cultivars BRS 295 RR and BRS 316 RR had yields that were similar to when grown alone, i.e., there was no reduction in yield when de soybean was intercropped with this fodder grass species. In contrast, the yield of cv. BRS 294 RR was higher when grown alone than when intercropped with the fodder grass grown under suppression (Table 3 ).

The number of grains per pod, 1,000-grain weight, and the yields of the three soybean cultivars intercropped with $U$. brizantha did not differ among intercropping treatments (Table 4). However, the number of pods per plant for cv. BRS 294 RR was higher in the absence of $U$. brizantha. For the other

Table 2. Growth characteristics of the three soybean cultivars, when grown under different cropping treatments with the fodder grass Urochloa brizantha, during the 2011/2012 growing season (Londrina, Paraná State, southern Brazil).

\begin{tabular}{lccc}
\hline Treatment & $\begin{array}{c}\text { Number of } \\
\text { branches per } \\
\text { plant }\end{array}$ & $\begin{array}{c}\text { First pod } \\
\text { insertion } \\
\text { height }(\mathrm{cm})\end{array}$ & $\begin{array}{c}\text { Plant } \\
\text { height } \\
(\mathrm{cm})\end{array}$ \\
\hline T3 & $\begin{array}{c}\text { Soybean cv. BRS } \\
295 R R(\text { Experiment } 4)\end{array}$ \\
T4 & $1.80 \mathrm{a}^{*}$ & $19.5 \mathrm{a}$ & $98.7 \mathrm{a}$ \\
$\mathrm{T} 1$ & $2.37 \mathrm{a}$ & $18.8 \mathrm{a}$ & $97.7 \mathrm{a}$ \\
$\mathrm{CV}(\%)$ & $1.90 \mathrm{a}$ & $17.6 \mathrm{a}$ & $98.5 \mathrm{a}$ \\
& 28.6 & 8.2 & 4.6 \\
$\mathrm{~T} 3$ & Soybean cv. BRS 316 RR (Experiment 5) \\
$\mathrm{T} 4$ & $3.75 \mathrm{a}$ & $22.8 \mathrm{a}$ & $116.4 \mathrm{a}$ \\
$\mathrm{T} 1$ & $3.92 \mathrm{a}$ & $21.7 \mathrm{a}$ & $111.6 \mathrm{a}$ \\
$\mathrm{CV}(\%)$ & $3.78 \mathrm{a}$ & $23.0 \mathrm{a}$ & $108.1 \mathrm{a}$ \\
& 16.6 & 13.0 & 5.5 \\
T3 & Soybean cv. BRS 294 RR (Experiment 6) \\
T4 & $4.35 \mathrm{ab}$ & $13.2 \mathrm{a}$ & $79.6 \mathrm{a}$ \\
$\mathrm{T} 1$ & $3.85 \mathrm{~b}$ & $12.8 \mathrm{a}$ & $79.0 \mathrm{a}$ \\
$\mathrm{CV}(\%)$ & $4.95 \mathrm{a}$ & $13.3 \mathrm{a}$ & $78.4 \mathrm{a}$ \\
\hline
\end{tabular}

* Means followed by the same letter within a column do not differ significantly among each other by the Tukey's HSD test $(p>0.05)$, considering each experiment individually. T3: soybean with fodder grass, with growth suppressed by glyphosate; T4: soybean with fodder grass, without growth suppression; T1: soybean only, without the fodder grass. 
Table 3. Yield components and yields of the three soybean cultivars, when grown under different cropping treatments with the fodder grass Urochloa ruziziensis, during the 2011/2012 cropping season (Londrina, Paraná State, southern Brazil).

\begin{tabular}{|c|c|c|c|c|}
\hline Treatment & $\begin{array}{l}\text { Number } \\
\text { of pods } \\
\text { per plant }\end{array}$ & $\begin{array}{c}\text { Number } \\
\text { of grains } \\
\text { per pod }\end{array}$ & $\begin{array}{l}\text { 1,000-grain } \\
\text { weight }(g)\end{array}$ & $\begin{array}{c}\text { Yield } \\
\left(\mathrm{kg} \mathrm{ha}^{-1}\right)\end{array}$ \\
\hline & \multicolumn{4}{|c|}{ Soybean cv. BRS 295 RR (Experiment 1) } \\
\hline $\mathrm{T} 3$ & $72.1 \mathrm{a}^{*}$ & $2.47 \mathrm{a}$ & $109 \mathrm{a}$ & $3,276 \mathrm{a}$ \\
\hline $\mathrm{T} 4$ & $66.0 \mathrm{a}$ & $2.45 \mathrm{a}$ & $106 \mathrm{a}$ & $3,192 \mathrm{a}$ \\
\hline $\mathrm{T} 1$ & $71.5 \mathrm{a}$ & $2.43 \mathrm{a}$ & $106 \mathrm{a}$ & 3,401 a \\
\hline \multirow[t]{2}{*}{ CV (\%) } & 12.3 & 5.5 & 3.3 & 8.2 \\
\hline & \multicolumn{4}{|c|}{ Soybean cv. BRS 316 RR (Experiment 2) } \\
\hline $\mathrm{T} 3$ & $49.8 \mathrm{a}$ & $2.20 \mathrm{a}$ & $110 \mathrm{a}$ & $1,898 \mathrm{a}$ \\
\hline $\mathrm{T} 4$ & $45.0 \mathrm{a}$ & $2.25 \mathrm{a}$ & $109 \mathrm{a}$ & $2,075 \mathrm{a}$ \\
\hline $\mathrm{T} 1$ & $61.2 \mathrm{a}$ & $2.23 \mathrm{a}$ & $112 \mathrm{a}$ & $2,507 \mathrm{a}$ \\
\hline \multirow[t]{2}{*}{$\mathrm{CV}(\%)$} & 22.7 & 7.6 & 7.3 & 25.3 \\
\hline & \multicolumn{4}{|c|}{ Soybean cv. BRS 294 RR (Experiment 3) } \\
\hline $\mathrm{T} 3$ & $58.1 \mathrm{a}$ & $2.55 \mathrm{a}$ & $144 \mathrm{a}$ & $2,728 \mathrm{~b}$ \\
\hline $\mathrm{T} 4$ & $52.3 \mathrm{a}$ & $1.95 \mathrm{a}$ & $144 \mathrm{a}$ & $3,094 \mathrm{ab}$ \\
\hline $\mathrm{T} 1$ & $51.0 \mathrm{a}$ & $2.15 \mathrm{a}$ & $151 \mathrm{a}$ & $3,206 \mathrm{a}$ \\
\hline CV $(\%)$ & 24.0 & 21.0 & 6.4 & 7.7 \\
\hline
\end{tabular}

* Means followed by the same letter within a column do not differ significantly among each other by the Tukey's HSD tests $(p>0.05)$, considering each experiment individually. T3: soybean with fodder grass, with growth suppressed by glyphosate; T4: soybean with fodder grass, without growth suppression; $\mathrm{T} 1$ : soybean only, without the fodder grass.

two cultivars, the numbers of pods per plant were not influenced by the treatments.

In general, the sowing of fodder species after the emergence of soybean with the use of a $0.6 \mathrm{~m}$ spacing between rows was an effective practice for minimizing the competition between a fodder grass species and soybean cultivars. Considering similar experiments carried out in the Savannah (Cerrado) region of Brazil, Kluthcouski \& Aidar (2003) observed reductions in soybean yield of up to $75 \%$ because of the competition with $U$. brizantha, when cultivated simultaneously, although there was no growth reduction treatment of this forage species with herbicide. Nevertheless, they found no statistically significant difference between the yield of soybean grown alone or intercropped with $U$. brizantha, when this forage was sown at 20 or 30 days after the emergence of soybean plants, thus agreeing with results observed in this study.

Considering the six experiments, the results indicate that the growth suppression of the two grass species using sub-dosages of glyphosate had no meaningful impact on the three soybean cultivars. This result occurred because the herbicide application had
Table 4. Yield components and yields of the three soybean cultivars, when grown under different cropping treatments with the fodder grass Urochloa brizantha, during the 2011/2012 cropping season (Londrina, Paraná State, southern Brazil).

\begin{tabular}{|c|c|c|c|c|}
\hline Treatment & $\begin{array}{l}\text { Number } \\
\text { of pods } \\
\text { per plant }\end{array}$ & $\begin{array}{c}\text { Number } \\
\text { of grains } \\
\text { per pod }\end{array}$ & $\begin{array}{l}\text { 1,000-grain } \\
\text { weight }(\mathrm{g})\end{array}$ & $\begin{array}{c}\text { Yield } \\
\left(\mathrm{kg} \mathrm{ha}^{-1}\right)\end{array}$ \\
\hline & \multicolumn{4}{|c|}{ Soybean cv. BRS 295 RR (Experiment 4) } \\
\hline $\mathrm{T} 3$ & $65.1 \mathrm{a}^{*}$ & $2.55 \mathrm{a}$ & $109 \mathrm{a}$ & $3,195 \mathrm{a}$ \\
\hline $\mathrm{T} 4$ & $71.7 \mathrm{a}$ & $2.42 \mathrm{a}$ & $100 \mathrm{a}$ & $3,355 \mathrm{a}$ \\
\hline $\mathrm{T} 1$ & $66.6 \mathrm{a}$ & $2.33 \mathrm{a}$ & $103 \mathrm{a}$ & $3,279 \mathrm{a}$ \\
\hline \multirow[t]{2}{*}{$\mathrm{CV}(\%)$} & 16.1 & 8.3 & 4.0 & 6.3 \\
\hline & \multicolumn{4}{|c|}{ Soybean cv. BRS $316 R R$ (Experiment 5) } \\
\hline $\mathrm{T} 3$ & $60.8 \mathrm{a}$ & $2.20 \mathrm{a}$ & $114 \mathrm{a}$ & $2,693 \mathrm{a}$ \\
\hline $\mathrm{T} 4$ & $59.6 \mathrm{a}$ & $2.60 \mathrm{a}$ & $113 \mathrm{a}$ & $2,459 \mathrm{a}$ \\
\hline $\mathrm{T} 1$ & $62.8 \mathrm{a}$ & $2.25 \mathrm{a}$ & $114 \mathrm{a}$ & $2,747 \mathrm{a}$ \\
\hline \multirow[t]{2}{*}{$\mathrm{CV}(\%)$} & 14.2 & 21.6 & 5.5 & 9.6 \\
\hline & \multicolumn{4}{|c|}{ Soybean cv. BRS 294 RR (Experiment 6) } \\
\hline $\mathrm{T} 3$ & $64.8 \mathrm{ab}$ & $2.25 \mathrm{a}$ & $137 \mathrm{a}$ & $2,819 \mathrm{a}$ \\
\hline $\mathrm{T} 4$ & $50.4 \mathrm{~b}$ & $2.17 \mathrm{a}$ & $146 \mathrm{a}$ & $2,931 \mathrm{a}$ \\
\hline $\mathrm{T} 1$ & $75.6 \mathrm{a}$ & $2.06 \mathrm{a}$ & $146 \mathrm{a}$ & $2,935 \mathrm{a}$ \\
\hline CV (\%) & 15.1 & 5.5 & 5.7 & 12.4 \\
\hline
\end{tabular}

* Means followed by the same letter within a column do not differ significantly among each other by the Tukey's HSD tests $(p>0.05)$, considering each experiment individually. T3: soybean with fodder grass, with growth suppressed by glyphosate; T4: soybean with fodder grass, without growth suppression; T1: soybean only, without the fodder grass.

little or no effect on the fodder grasses (Tables 5 and 6), most likely because of the low dosage used, as well as the protection effect produced by soybean canopy, which prevented the herbicide from reaching the grass. The late sowing of the two Urochloa species, in relation to the sowing of soybean, could also have contributed to the low impact of the growth suppression by the glyphosate treatment on soybean yields.

In addition to glyphosate, other herbicides may be used to reduce the growth of fodder grasses intercropped with soybean. The herbicide fluazifopp-butyl has exhibited a high potential for suppressing the growth of $U$. brizantha, when intercropped with soybean (Silva et al. 2004) or common bean (Silva et al. 2006). Portela (2003) concluded that there was no statistically significant difference between the yield of a non-transgenic soybean cultivar, when grown alone or intercropped with $U$. brizantha with growth suppression by the application of sub-dosages of haloxyfop-methyl, at 60 days after soybean emergence. Mariani et al. (2012) also found that the soybean yield was not reduced by intercropping with $U$. brizantha with growth reduction by the application of sub-dosages of fluazifop-p-butyl. 
The plant heights and shoot dry mass yields of $U$. ruziziensis and $U$. brizantha evaluated at the soybean harvest were generally higher when grown alone, if compared to the intercropped treatments (Tables 5 and 6), which agrees with the results obtained by Portela (2003) and Mariani et al. (2012). Nevertheless, the plant heights and shoot dry mass yields of the fodder grasses were not influenced by the glyphosate application in any of the six experiments evaluated (Tables 5 and 6). In contrast, Portela (2003) and Silva et al. (2004) observed reductions in the biomass of $U$. brizantha intercropped with soybean of up to $83 \%$, as a function of sub-dosages of haloxyfopmethyl or fluazifop-p-butyl applications.

The production of shoot biomass by the fodder grasses intercropped with soybean was high (generally higher than $3 \mathrm{t} \mathrm{ha}^{-1}$ ), indicating the high potential for fodder production by the $U$.ruziziensis and $U$. brizantha species, when cultivated in association with soybean, without significantly influencing the soybean yields. These findings may contribute to the optimization of the land use for CLS, and also suggest the potential for a high biomass production, when these fodder grasses are used as cover crops. According to Franchini et al.

Table 5. Plant heights and shoot dry mass yields (after the harvest of soybean) of the fodder grass Urochloa ruziziensis, subjected to different cropping treatments, during the 2011/2012 cropping season (Londrina, Paraná State, southern Brazil).

\begin{tabular}{|c|c|c|}
\hline Treatment & $\begin{array}{l}\text { Plant height } \\
(\mathrm{cm})\end{array}$ & $\begin{array}{c}\text { Shoot dry mass } \\
\left(\mathrm{kg} \mathrm{ha}^{-1}\right)^{* *}\end{array}$ \\
\hline & \multicolumn{2}{|c|}{ Soybean cv. BRS 295 RR (Experiment 1) } \\
\hline $\mathrm{T} 3$ & $29.9 b^{*}$ & $2,733 \mathrm{~b}$ \\
\hline $\mathrm{T} 4$ & $31.8 \mathrm{~b}$ & $5,407 \mathrm{ab}$ \\
\hline $\mathrm{T} 2$ & 99.9 a & $12,818 \mathrm{a}$ \\
\hline \multirow[t]{2}{*}{ CV $(\%)$} & 10.9 & 39.5 \\
\hline & \multicolumn{2}{|c|}{ Soybean cv. BRS 316 RR (Experiment 2) } \\
\hline $\mathrm{T} 3$ & $35.4 \mathrm{~b}$ & $5,767 \mathrm{~b}$ \\
\hline $\mathrm{T} 4$ & $59.0 \mathrm{~b}$ & $5,616 \mathrm{~b}$ \\
\hline $\mathrm{T} 2$ & $105.5 \mathrm{a}$ & $11,218 \mathrm{a}$ \\
\hline \multirow[t]{2}{*}{$\mathrm{CV}(\%)$} & 20.5 & 20.4 \\
\hline & \multicolumn{2}{|c|}{ Soybean cv. BRS 294 RR (Experiment 3) } \\
\hline $\mathrm{T} 3$ & $32.7 \mathrm{~b}$ & $3,794 \mathrm{~b}$ \\
\hline $\mathrm{T} 4$ & $53.6 \mathrm{ab}$ & $7,784 \mathrm{ab}$ \\
\hline $\mathrm{T} 2$ & $85.4 \mathrm{a}$ & $14,892 \mathrm{a}$ \\
\hline CV $(\%)$ & 31.4 & 39.6 \\
\hline
\end{tabular}

(2012), the use of cropping systems that enable a high amount of biomass production is important for the appropriate management of NTS. In CLS, the availability of pasture in the off-season of summer crops is important for maintaining an adequate supply of forage to cattle (Balbinot Junior et al. 2009, Balbino et al. 2011).

In the six independent experiments conducted to evaluate the biological efficiency of the intercropping of soybean with Urochloa species, with or without suppression by glyphosate, the LUE indices were all higher than 1 (Table 7). These values indicate the complementarity between the soybean cultivars and the fodder species, thus enhancing the use of water, light, and nutrients. A LUE index value greater than 1 indicates an advantage of the intercropped system, in relation to sole cropping (Bezerra et al. 2007).

In the present study, the mechanical harvest of soybean was hampered by the heights of the fodder grasses (Tables 5 and 6 ) because the fodder grasses were taller than the first pod insertion height (Tables 1 and 2). As a result of this situation, some cutting of the leaves and stalks of the grasses occurred, which may impair the harvest efficiency and/or increase the moisture content of the soybean grains.

Table 6. Plant heights and shoot dry mass yields (after the harvest of soybean) of the fodder grass Urochloa brizantha, subjected to different cropping treatments, during the 2011/2012 cropping season (Londrina, Paraná State, southern Brazil).

\begin{tabular}{lcc}
\hline Treatment & $\begin{array}{c}\text { Plant height } \\
(\mathrm{cm})\end{array}$ & $\begin{array}{c}\text { Shoot dry mass } \\
\left(\mathrm{kg} \mathrm{ha}^{-1}\right)^{* *}\end{array}$ \\
\hline & Soybean cv. BRS 295 RR $($ Experiment 4$)$ \\
T3 & $35.6 \mathrm{~b}^{*}$ & $3,897 \mathrm{~b}$ \\
T4 & $39.3 \mathrm{~b}$ & $4,945 \mathrm{~b}$ \\
T2 & $119.1 \mathrm{a}$ & $14,906 \mathrm{a}$ \\
CV $(\%)$ & 12.3 & 23.0 \\
\hline & Soybean cv. BRS 316 RR (Experiment 5) \\
T3 & $35.5 \mathrm{~b}$ & $4,748 \mathrm{ab}$ \\
T4 & $42.7 \mathrm{~b}$ & $4,376 \mathrm{~b}$ \\
T2 & $120.1 \mathrm{a}$ & $12,391 \mathrm{a}$ \\
CV $(\%)$ & 12.6 & 28.6 \\
\hline & Soybean cv. BRS 294 RR (Experiment 6) \\
T3 & $52.5 \mathrm{~b}$ & $7,197 \mathrm{a}$ \\
T4 & $55.7 \mathrm{~b}$ & $9,119 \mathrm{a}$ \\
T2 & $20.0 \mathrm{a}$ & $10,170 \mathrm{a}$ \\
CV $(\%)$ & 14.3 & 24.3 \\
\hline
\end{tabular}

* Means followed by the same letter within a column do not differ significantly among each other by the Tukey's HSD tests $(p>0.05)$, considering each experiment individually; $* *$ Means transformed by $y=\sqrt{ } \mathrm{x}$. T3: fodder grass with growth suppressed by glyphosate; T4: fodder grass without growth suppression; T2: fodder grass only, without soybean. 
Table 7. Land Use Efficiency indices (LUE) of intercropping systems consisting of one of three soybean cultivars and one of two fodder grass species of the genus Urochloa, with and without fodder grass growth suppression with glyphosate, during the 2011/2012 cropping season (Londrina, Paraná State, southern Brazil).

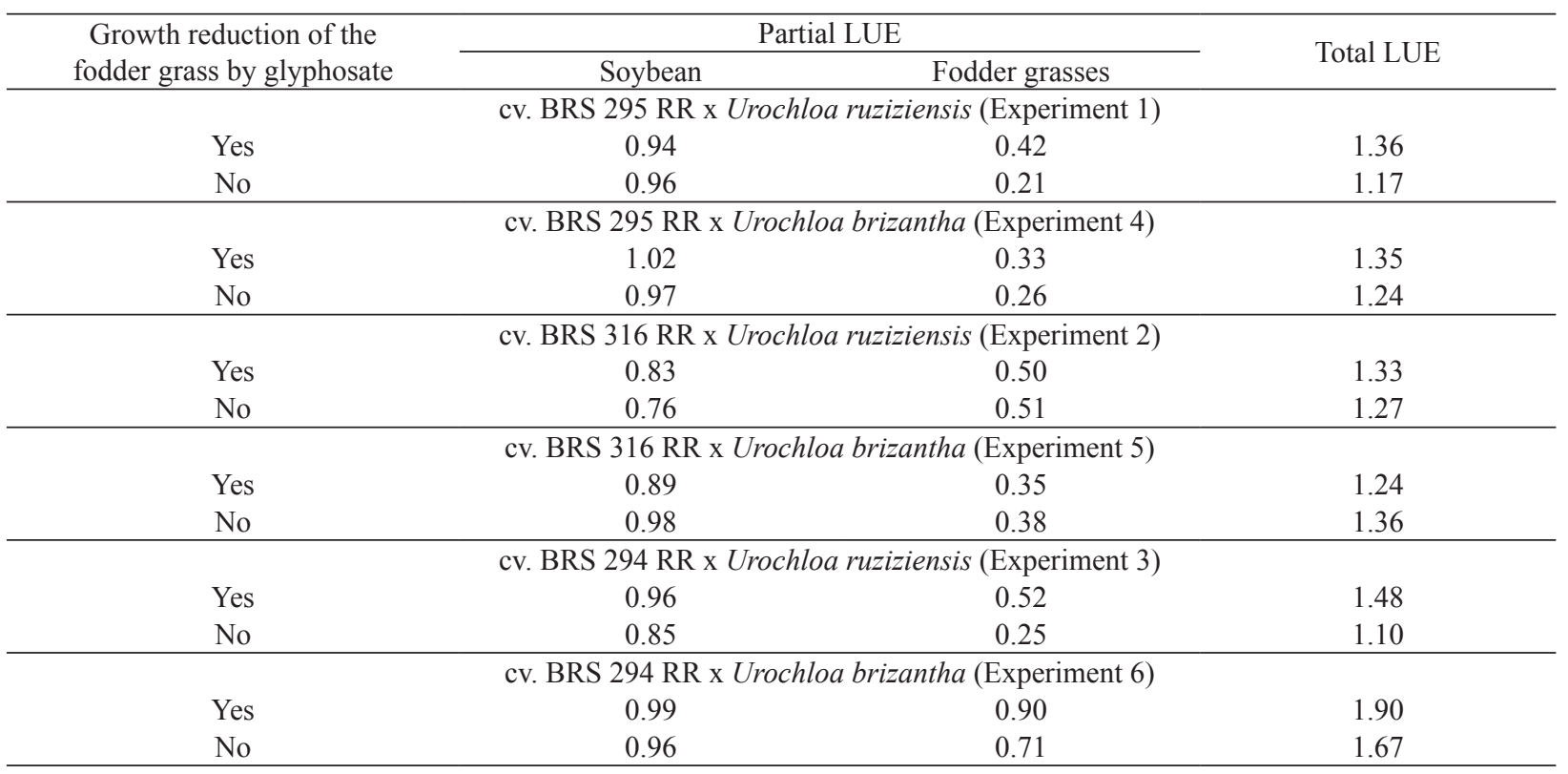

Mariani et al. (2012) reported similar problems for the mechanical harvesting of soybean intercropped with $U$. brizantha, even when grass growth was suppressed using sub-dosages of herbicides. Similarly, Kluthcouski \& Aidar (2003) reported an increase in grain losses during soybean harvest associated with intercropping with $U$. brizantha. Based on these challenges, one or a combination of measures may provide a solution, such as alternative forms of chemically delaying the growth of fodder grasses (substitution of herbicides, changes in the dosages and application times, in relation to the growth stage of the forage grass or level of closure of the soybean canopy); sowing of forage species during more advanced growth stages of soybean; and use of other fodder species intercropped with soybean, especially those presenting slower growth than the soybean crop.

\section{CONCLUSIONS}

1. The yields of the three soybean cultivars were not significantly affected by intercropping with the Urochloa grasses.

2. The shoot dry mass yields of the fodder grasses were high when intercropped with soybean, although lower than those obtained without any interference by soybean.
3. The suppression of the growth of $U$. ruziziensis and $U$. brizantha with glyphosate was not necessary because it did not enhance the soybean yield.

\section{REFERENCES}

ANDREWS, D. J.; KASSAM, A. H. The importance of multiple cropping in increasing world food supplies. In: AMERICAN SOCIETY OF AGRONOMY (ASA). Multiple cropping systems. Madison: ASA, 1976. p. 1-10.

BALBINO, L. C. et al. Evolução tecnológica e arranjos produtivos de sistemas de integração lavoura-pecuáriafloresta no Brasil. Pesquisa Agropecuária Brasileira, Brasília, DF, v. 46, n. 10, p. 1-12, 2011.

BALBINOT JUNIOR, A. A. et al. Integração lavourapecuária: intensificação de uso de áreas agrícolas. Ciência Rural, Santa Maria, v. 39, n. 6, p. 1925-1933, 2009.

BEZERRA, A. P. A. et al. Rendimento, componentes da produção e uso eficiente da terra nos consórcios sorgo $\mathrm{x}$ feijão-de-corda e sorgo x milho. Ciência Agronômica, Fortaleza, v. 38, n. 1, p. 104-108, 2007.

EMPRESA BRASILEIRA DE PESQUISA AGROPECUÁRIA (Embrapa). Centro Nacional de Pesquisa de Solos. Sistema brasileiro de classificação de solos. 2. ed. Brasília, DF: Embrapa, 2006. 
FERREIRA, D. F. Sisvar: um programa para análises e ensino de estatística. Revista Symposium, Lavras, v. 6, n. 1, p. 36-41, 2008.

FLECK, N. G. et al. Interferência de picão-preto e guanxuma com a soja: efeitos da densidade de plantas e época relativa de emergência. Ciência Rural, Santa Maria, v. 34, n. 1, p. 41-48, 2004.

FLECK, N. G. et al. Resposta de cultivares de soja à competição com cultivar simuladora da infestação de plantas concorrentes. Scientia Agraria, Curitiba, v. 8, n. 3, p. 213-218, 2007.

FRANCHINI, J. C. et al. Evolution of crop yields in different tillage and cropping systems over two decades in southern Brazil. Field Crops Research, Amsterdam, v. 137, n. 1, p. 178-185, 2012.

KLUTHCOUSKI, J.; AIDAR, H. Implantação, condução e resultados obtidos com o Sistema Santa Fé. In: KLUTHCOUSKI, J.; STONE, L. F.; AIDAR, H. (Eds.). Integração lavoura-pecuária. Santo Antônio de Goiás: Embrapa Arroz e Feijão, 2003. p. 407-442.
MARIANI, F. et al. Estabelecimento de gramíneas forrageiras tropicais perenes simultaneamente com as culturas de milho e soja no norte do RS. Ciência Rural, Santa Maria, v. 42, n. 8, p. 1471-1476, 2012.

PORTELA, C. M. O. Efeito de herbicidas e diferentes populações de forrageiras consorciadas com as culturas de soja e milho, no Sistema Santa Fé. 2003. 68 f. Dissertação (Mestrado em Agronomia) - Universidade Federal de Goiás, Goiânia, 2003.

SILVA, A. C. et al. Consórcio entre feijão e Brachiaria brizantha sob doses reduzidas de graminicidas. Planta Daninha, Viçosa, v. 24, n. 1, p. 71-76, 2006.

SILVA, A. C. et al. Efeitos de doses reduzidas de fluazifopp-butil no consórcio entre soja e Brachiaria brizantha. Planta Daninha, Viçosa, v. 22, n. 3, p. 429-435, 2004.

VEIGA, M. et al. Atributos de solo e de plantas afetados pelo manejo da pastagem anual de inverno em sistema integração lavoura-pecuária. Ciência Rural, Santa Maria, v. 42, n. 3, p. 444-450, 2012. 